\title{
Into the bazaar: Indian Ocean vernaculars in the age of global capitalism
}

\author{
Fahad Bishara ${ }^{1, \star}$ and Hollian Wint ${ }^{2}$ \\ ${ }^{1} 323$ Nau Hall, 1540 Jefferson Park Avenue, Charlottesville, VA 22904, USA and ${ }^{2} 6265$ Bunche Hall, Box 951473, University of \\ California Los Angeles, Los Angeles, CA 90095-1473, USA, E-mail: wint@history.ucla.edu \\ ${ }^{*}$ Corresponding author. E-mail: fab7b@virginia.edu
}

\begin{abstract}
Drawing on a far-flung, multilingual archive of contracts and financial instruments from around the western Indian Ocean, this article highlights how cross-cultural trade depended on the ability of groups to translate between one system and another, rendering one commercial lexicon legible to another so as to produce commensurability and allow for conversions to take place. Law constituted a foundational building block of this process: Indian Ocean merchants drew on a deep well of legal concepts and forms as they attempted to make their worlds legible to one another, mobilizing the grammars of law to bridge commercial systems. We situate these dynamics within the context of the Indian Ocean 'bazaar', establishing it as a site for thinking about the place of cross-cultural trade in world history, and the histories of global capitalism more broadly. We suggest that EuroAmerican capitalism's very agents had to adapt their commerce to the idioms, logics, and contracts of their business partners around the Indian Ocean - a vernacular world of the bazaar that was itself already in motion.
\end{abstract}

Keywords: capitalism; cross-cultural trade; Indian Ocean

It was the new year in 1840 when Richard Waters, the recently appointed American consul in Zanzibar, wrote a note to the person who was going to temporarily relieve him of his duty, instructing him on how to conduct business on behalf of merchants visiting the island. 'After you have engaged to the business of any vessel, you will do well to hold a conversation with Jeram bin Seva [Jairam Sewji], the Custom Master. Inform him what the vessel has to sell and what she wishes for return cargo.' He then went on to emphasize the process by which a deal was closed: 'After understanding a bargain distinctly, it will be necessary to close it by shaking hands .... Soon after, draw up a written contract in duplicate .... Retain one yourself, and one hand to Jeram', adding that 'a more safe \& expeditious business can be done with Jeram, than all the other merchants put together in Zanzibar'.

The fact of an American consul in Zanzibar might not be surprising: though there had been an 'American' presence in the Indian Ocean since the 1700s, in the decades following the American Revolution an independent network of US merchants began expanding into South and East Asia. ${ }^{2}$

\footnotetext{
${ }^{1}$ Richard P. Waters to P. Starr Parker, Zanzibar, 1 January 1840, published in Richard Bennett, ed., New England Merchants in Africa: A History Through Documents, 1802-1865 (Boston: Boston University Press, 1965): 225.

${ }^{2}$ See also James Fichter, So Great a Proffit: How the East Indies Transformed Anglo-American Capitalism (Cambridge, MA: Harvard University Press, 2010).

(c) The Author(s), 2020. Published by Cambridge University Press.
} 


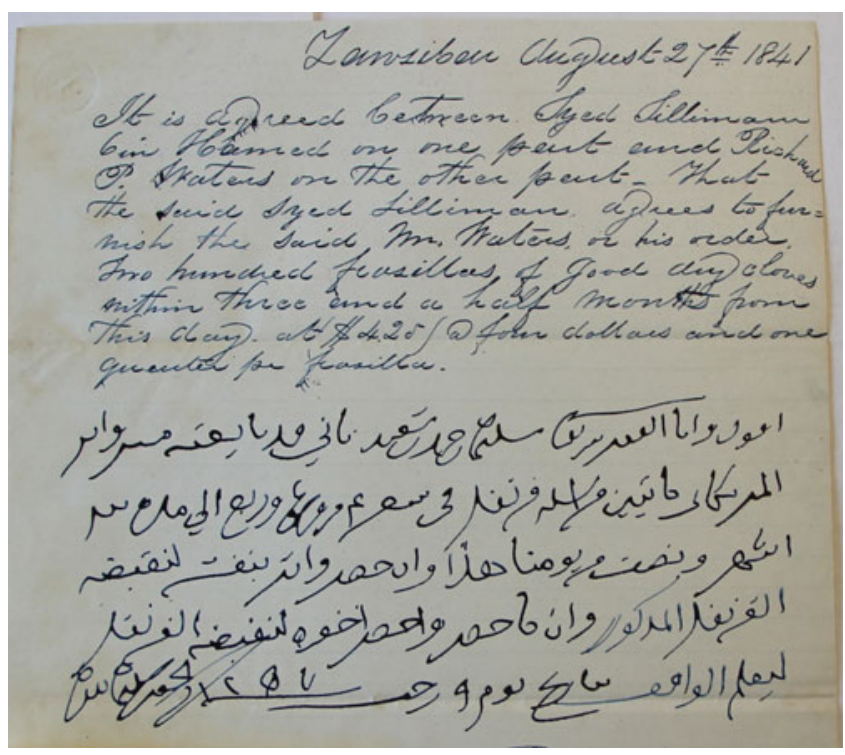

Figure 1. An 1841 contract between Richard Waters and Sulaiman bin Hamad Al-Busa'idi (in English and Arabic) for the delivery of roughly 7,000 lbs of cloves. Source: Richard P. Waters Papers, MH14 Box 2, Folder 6, PEM.

East Africa constituted another frontier in that regard, and American merchants appeared in increasing numbers beginning in the $1820 \mathrm{~s}^{3}$ Nor might Waters' reliance on the Indian customs master for all of his business itself be surprising. Zanzibar, which by 1840 had become a thriving entrepôt for goods coming into and out of East Africa, was also home to a sizeable Indian merchant community, many of whom occupied prominent positions in commerce and public finance. Nor will readers of Waters' letters be too taken aback by his insistence that a bargain be concluded in writing, and that copies of the contract be retained by both parties to the transaction. After all, by the nineteenth century the custom of writing down contracts had become standard practice among merchants in the Atlantic and Indian Ocean alike.

The contracts themselves, however, are intriguing. Waters left behind a small collection of them - roughly one hundred in all - allowing us to peer into the transactional world that he and other American merchants entered into. The forms themselves are unremarkable, and appear to be standard English agreements for the delivery of the commodities that American merchants sent back: hides, gum copal, cloves, and so on. What is interesting, however, is that roughly twenty-five of them sit side by side with copies of the contracts in other languages: some in Arabic, others in Gujarati. In one such document from 1841 (see Figure 1), Richard Waters contracted with Sulaiman bin Hamad Al-Busaidi, a relative of the Sultan of Muscat and Zanzibar, for the delivery of 200 frasilas $(7,000 \mathrm{lbs})$ of cloves. At the bottom of the document, the contract was reproduced in Arabic, in full. In another from that same year (see Figure 2), Waters wrote out an agreement with a 'Isa bin 'Abdulrahman in which the latter pledged to deliver 500 frasilas (17,500 lbs) of gum copal over the course of three months, in two separate instalments. Like the contract for cloves, the gum copal contract also included a body of writing at the bottom, this time in Gujarati. ${ }^{4}$

\footnotetext{
${ }^{3}$ Cyrus Townsend Brady, Jr, Commerce and Conquest in East Africa, With Particular Reference to the Salem Trade with Zanzibar (Salem, MA: Peabody Essex Institute, 1950); Norman Robert Bennett, 'Americans in Zanzibar: 1825-1845', Essex Institute Historical Collections 95 (1959): 239-62.

${ }^{4}$ Richard P. Waters Papers, MH14 Box 2, Folder 6, Philips Library, Peabody Essex Museum, Salem, MA (hereafter cited as PEM). We are grateful to Joshua Morrison and Nicholas Roberts for help in obtaining these records.
} 


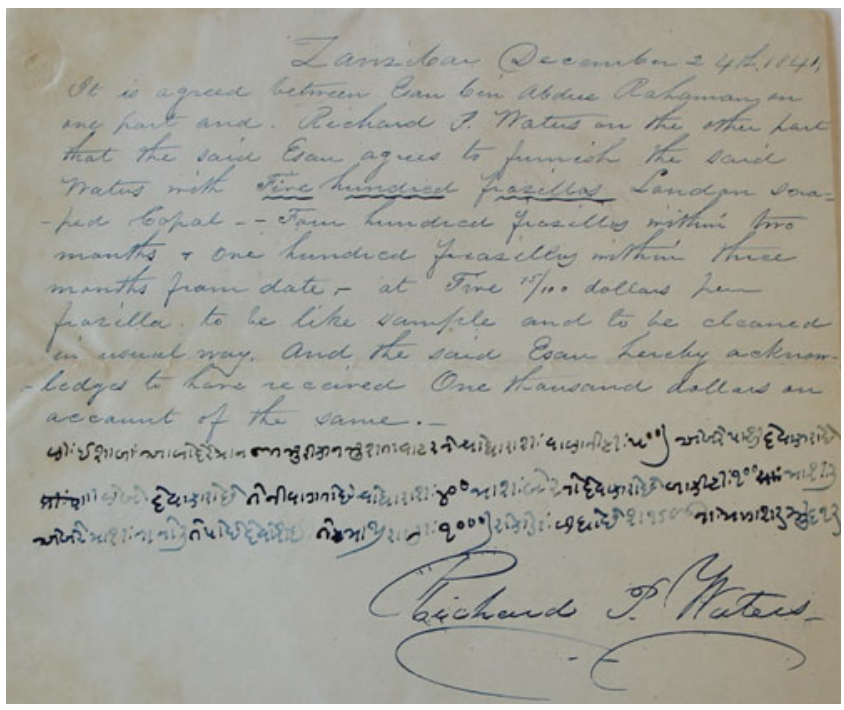

Figure 2. An 1841 contract between Richard Waters and 'Isa bin 'Abdulrahman (in English and Gujarati) for the delivery of roughly 17,500 lbs of gum copal. Source: Richard P. Waters Papers, MH14 Box 2, Folder 6, PEM.

The existence of these parallel contracts - which make up roughly a quarter of the contracts that Waters held onto - serves as a concrete illustration of what world historians since Philip Curtin have labelled 'cross-cultural trade', a broad phenomenon that recent studies have given more analytic depth to. ${ }^{5}$ The documents manifestly demonstrate the process by which commodities and credit moved between one commercial group, the merchants of New England, and another, the Arab-Gujarati-Swahili merchant communities of East Africa and the Indian Ocean more broadly. As a historical phenomenon, cross-cultural trade sheds light on a process of brokerage between commercial communities and, by extension, between mercantile systems. And yet, as the documents themselves highlight, cross-cultural brokerage depended on the ability of groups to translate between commercial worlds, rendering one vernacular legible to another so as to produce commensurability and allow for conversions to take place - the very preconditions of commerce itself. We take heed of Ronit Ricci's call to think of translation in 'social terms', paying attention to modes of translation between forms, genres, and scales, and also to whether translation intends to render equivalent or to transmit, interpret, and convert. ${ }^{6}$ We thus ask: which contract is a translation - or rather, a telling - of which, and what might a reading of the directionality tell us about the phenomenon as a whole?

If cross-cultural trade and contracting rested on a textured process of translation, law furnished the toolkit for that process to emerge. Indian Ocean merchants drew on a deep well of legal concepts and forms as they attempted to make their worlds legible to one another, mobilizing

\footnotetext{
${ }^{5}$ Philip D. Curtin, Cross-Cultural Trade in World History (New York: Cambridge University Press, 1984). Historians such as Claude Markovits, Sebouh Aslanian, and Francesca Trivellato have helped re-conceive cross-cultural trade as a more contractual phenomenon, shedding light on long-term credit ties between communities. Claude Markovits, The Global World of Indian Merchants, 1750-1947: Traders of Sind from Bukhara to Panama (New York: Cambridge University Press, 2006); Sebouh D. Aslanian, From the Indian Ocean to the Mediterranean: The Global Trade Networks of Armenian Merchants from New Julfa (Berkeley: University of California Press, 2011); Francesca Trivellato, The Familiarity of Strangers: Sephardic Jews, Livorno, and Cross-Cultural Trade in the Early Modern World (New Haven: Yale University Press, 2009), 21-43.

${ }^{6}$ Ronit Ricci, Islam Translated: Literature, Conversion, and the Arabic Cosmopolis of South and Southeast Asia (Chicago: University of Chicago Press, 2011), 31-65. On translation and colonial encounters, see Michael Gilsenan, 'Translating Colonial Fortunes: Dilemmas of Inheritance in Muslim and English Laws Across a Nineteenth-Century Diaspora', Comparative Studies of South Asia, Africa and the Middle East 31, no. 2 (2011): 355-71.
} 
the grammars of law to bridge commercial systems. And as they did that, they engaged with a variety of legal institutions and service providers, stretching their contractual forms to fit the contours of a changing juridical landscape. We thus understand law to include courts and tribunals, but also much more: it comprised a lexicon of transactional concepts, forms, and practices that merchants would draw on, give shape to, connect to one another, and present to a variety of institutions for myriad purposes. In this form, law constituted a foundational building block of cross-cultural trade, both in the Indian Ocean and beyond.

The Richard Waters papers thus reflect a moment in which Euro-American capital, personified by Waters and the interests he represented, had to come to terms with the contractual world of the Indian Ocean - 'the world of the bazaar', as we very deliberately call it here. For social scientists, 'the bazaar' has been a physical site, but also an analytic idea: a marketplace of buyers and sellers characterized by a high velocity of exchanges, often very local in their dimensions. ${ }^{7}$ By contrast, historians have been inclined towards an understanding of the bazaar as a one of the frontiers of Euro-American capitalism - a site of 'intermediary' capital, in which Indian merchants mediated between large financial institutions in the Subcontinent and more peripheral markets around the Indian Ocean, but played a subordinate role to Euro-American capital. ${ }^{8}$

We understand the bazaar less as a physical space than as a historical phenomenon. We see it as a market - a money market, yes, but more broadly a field of connected and overlapping contractual and transactional processes and artefacts, grounded in a broad and pluralistic world of law. Though these practices often take place in the locus of the bazaar, and the principal actors are often shopkeepers, thinking capaciously about the world of the bazaar necessitates that we decouple it from the physical space itself and open it up as a site from which we might think (and write) about history more broadly. Here, we are principally concerned with the vernaculars of the maritime bazaars of the western Indian Ocean - extending from Basra, in southern Iraq, to Zanzibar, in East Africa - and their articulation with a moment of Euro-American capitalism in that ocean. As the circuits of global commerce and finance anchored themselves in the Indian Ocean world, bazaar merchants grounded them in vernacular forms of contracting, transmuting Euro-American capital into local capital and suturing it with a range of different local instruments. These contracts (for which we have thousands of preserved examples) were often local in character, detailing transactions in credit, property, and labour - in obligations, more broadly. Despite their local character, however, these were anything but local transactions: many took a distinctly transregional character, and a number pointed to the boundaries between the Indian Ocean world and the global economy in which it had become firmly integrated.

Our understanding of the term 'vernacular', then, disrupts a binary between vernacular and cosmopolitan, local and global. As Sheldon Pollock conceived of the vernacular and cosmopolitan dialectically and dynamically, we suggest intersecting Indian Ocean vernaculars that functioned on multiple scales. ${ }^{9}$ Both Arabic and Gujarati contracts were decidedly 'creole' in nature, transliterating concepts and terms from the overlapping languages of the Indian Ocean - Kiswahili and English, as well as Gujarati and Arabic - with which the contracting parties would have been familiar, if not fluent. ${ }^{10}$ Arabic, of course, simultaneously worked on a more cosmopolitan scale,

\footnotetext{
${ }^{7}$ The standard reference in writings on the bazaar is Clifford Geertz's 'The Bazaar Economy: Information and Search in Peasant Marketing', American Economic Review 68, no. 2 (1978): 28-32. Geertz's article gave rise to other studies in different settings. See also Frank Fanselow, 'The Bazaar Economy, or How Bizarre Is the Bazaar Really?', Man 25, no. 2 (1990): 250-65; Arang Keshavarzian, Bazaar and State in Iran: The Politics of the Tehran Marketplace (New York: Cambridge University Press, 2007).

${ }^{8}$ Sugata Bose, A Hundred Horizons: The Indian Ocean in the Age of Global Empire (Cambridge, MA: Harvard University Press, 2006), 77.

${ }^{9}$ Sheldon Pollock, 'The Cosmopolitan Vernacular', Journal of Asian Studies 57, no. 1 (1998): 6-37.

${ }^{10} \mathrm{On}$ Kiswahili as a regional language in the nineteenth century, see Tom Hoogervorst, 'Sailors, Tailors, Cooks, and Crooks: On Loanwords and Neglected Lives in Indian Ocean Ports', Itinerario 42, no. 3 (2018): 516-48. We have seen far fewer Kiswahili contracts for the nineteenth century, and have not attempted to incorporate them into our analysis. That said,
} 
inscribing legal concepts and lexicons that were shared and contested throughout the Islamic world. ${ }^{11}$ Indeed, in the western Indian Ocean, the lexicons of Islamic law provided a universal grammar, with both Muslims and non-Muslims carrying out the bulk of their transactions in Arabic contracts. These contracts were transmitted and converted into Gujarati financial and accounting instruments, and often back again, rendering them increasingly commensurable in form and content. Indian Ocean actors of various origins and creeds thus came to share similar ideas about and means of measuring and transacting the value of things, property, and people.

To be clear, we do not employ vernacular as a cultural concept; Indian Ocean vernaculars did not map onto 'ethnic', racial, or religious boundaries and the commercial world of the western Indian Ocean was dominated by interfaith and intercommunal transactions. ${ }^{12}$ Nor do we pit a 'global' (that is, Euro-American) contractual grammar against a 'vernacular' (that is, Asian) one; Waters' contracts and others like them were neither more global in their outlook nor more portable in their usage than those employed by Indian Ocean merchants. Rather, the vernacular concept is a means to explore the logics, grammars, and intellectual histories that emerge from the bazaar itself, as unbounded and broad as it is. ${ }^{13}$

Our main interest here lies in the emergence and transformation of an Indian Ocean commercial grammar during the long nineteenth century, a period of rapid economic and political transformation, but also of institutional change. Indian Ocean historians have long recognized that the nineteenth century marked a break from what came before it. The onset of the Industrial Revolution and its articulation with the British imperial project in the Indian Ocean - as manifested in steamships, telegraphs, banks, and other technological transformations, but also in the rapid proliferation of consular and colonial courts - remade the foundations of commerce in the region. This, coupled with the advent of a series of interlinked commercial booms during the nineteenth century and a concomitant influx of European and American merchants, forces us to reflect on the ways in which Indian Ocean actors remade their world of contracting to meet new opportunities. Because of spatial constraints, we end our analysis before the coming of the worldwide economic depression in the 1930s, which marked another watershed moment in the world of Indian Ocean commerce.

Within this period of growth and transformation, Euro-American capital could not take root anywhere in the western Indian Ocean without translating itself into the vernacular world of transactions. The language of local contracting (which itself formed the contractual basis of transregional exchange) made up the transactional idiom in which European and American merchants entering the Indian Ocean arena found themselves entangled. In making this claim, we take seriously Jeremy Adelman's invitation to write histories that can 're-signify the place of local attachments and meanings' while still maintaining their broad scope and ambition - an

\footnotetext{
the few that do survive are ajami documents and thus point to another intersection of commercial vernaculars, as well as the intercommunal nature of the societies producing them.

${ }^{11}$ Ricci follows Pollock in coining the term 'Arabic cosmopolis', but also notes both that translation was one of the 'foundational practices' of the Arabic cosmopolis and that the result was a process by which Arabic was 'vernacularized' as much as vernaculars were 'Arabized'. This dynamic dialectic is useful for understanding the Indian Ocean context more broadly. Ricci, Islam Translated, 14-17.

${ }^{12}$ By emphasizing interfaith and intercommunal transactions, our analysis runs counter to much of the existing scholarship on Indian Ocean trading networks. Recent examples of this scholarship include Aslanian, From the Indian Ocean, and Pedro Machado, Ocean of Trade: South Asian Merchants, Africa and the Indian Ocean, c. 1750-1850 (New York: Cambridge University Press, 2014).

${ }^{13} \mathrm{We}$ acknowledge that historians of South Asia have problematized the notion of the vernacular within the literature, particularly its position within a colonial discourse that produced bounded 'native' worlds. See Ritu Birla, Stages of Capital: Law, Culture, and Market Governance in Late Colonial India (Durham, NC: Duke University Press, 2009). By contrast, we suggest that the bazaar's vernacular, like the commercial culture of the Indian Ocean world, is unbounded.
} 
enterprise which, some argue, lies at the core of the field of global history itself. ${ }^{14}$ At the same time, in writing a history that involves multiple locales from around the Indian Ocean, we shed light on the shape of global capitalism as a whole - a vantage point from which it appears in a piecemeal way, integral to and embedded in discontinuous, multi-sited objects of study'. ${ }^{15}$ Rather than repeat the well-established argument that capitalism, either through processes of local articulation or through total erasure, reconfigured Africa and Asia into its 'global countryside', we want to suggest that Euro-American capitalism's very agents had to adapt their commerce to the idioms, logics, and contracts of their business partners around the Indian Ocean - a vernacular world that was itself already in motion. Global capitalism, we argue, emerged out of the moments of interface that we see in the papers of Richard Waters.

In emphasizing these moments of interface, we bring a degree of transactional granularity to a well-established line of analysis on Euro-Asian encounters. ${ }^{16}$ One might begin with Christopher Bayly and Lakshmi Subramanian's assertions that East India Company expansion into India relied on local networks of financiers, and more recently with Jeremy Prestholdt's masterful rerouting of the circuits of global commerce, in which he places East African consumers at the centre of the narrative. In the realm of administration, Bhavani Raman's work masterfully lays out the degree to which the East India Company bureaucracy was, at least initially, anchored in the vernacular world of the Cutcherry scribe. ${ }^{17}$ Historians have thus come to a broad consensus that European expansion in the Indian Ocean depended on local actors, institutions, and processes. Thus, Rajat Kanta Ray characterized his study of the Indian Ocean bazaar economy as exploring 'an encounter between a global system of credit and trade centered on Europe, and an Indian Ocean financial nexus dealing in negotiable instruments on principles that had evolved independently of those of the Western banks'. ${ }^{18}$

But rather than imagine a world in which commercial systems ran parallel to one another and occasionally intersected, we want to suggest that historians might fruitfully conceive of a process by which they actively reckoned with one another. ${ }^{19}$ The long nineteenth century was a global 'moment' in which different economic actors from around the world bent their transactional lexicons so as to accommodate one another's contractual and commercial impulses. The maritime bazaar in the western Indian Ocean itself formed the site of translations between different contractual vernaculars, conversions between local and regional forms of value, and arbitrage between different markets in the pursuit of marginal gains. ${ }^{20}$ And with its many transformations,

\footnotetext{
${ }^{14}$ Jeremy Adelman, 'What Is Global History Now?', Aeon, 2 March 2017, https://aeon.co/essays/is-global-history-stillpossible-or-has-it-had-its-moment; Richard Drayton and David Montadel, 'Discussion: The Futures of Global History', Journal of Global History 13, no. 1 (2018): 1-21.

${ }^{15}$ George E. Marcus, Ethnography Through Thick and Thin (Princeton: Princeton University Press, 1998), 81-3.

${ }^{16} \mathrm{~A}$ similar scholarship exists for the Atlantic world. See, for example, Jane Guyer, from whom we adopt the notion of 'interface': Jane Guyer, Marginal Gains: Monetary Transactions in Atlantic Africa (Chicago: University of Chicago Press, 2004), 40.

${ }^{17}$ Bhavani Raman, Document Raj: Writing and Scribes in Early Colonial South Asia (Chicago: University of Chicago Press, 2012); Jeremy Prestholdt, Domesticating the World: Globalization and the Genealogies of East African Consumerism (Berkeley: University of California Press, 2006); Lakshmi Subramanian, Indigenous Capital and European Expansion: Bombay, Surat, and the West Coast (Oxford: Oxford University Press, 1996); Christopher Bayly, Rulers, Townsmen, and Bazaars: North Indian Society in the Age of British Expansion, 1770-1870 (New York: Cambridge University Press, 1988).

${ }^{18}$ Rajat Kanta Ray, 'Asian Capital in the Age of European Domination: The Rise of the Bazaar, 1800-1914', Modern Asian Studies 29, no. 3 (1995): 552. These scholars, of course, intervene in a much larger debate about 'proto-capitalism' in South Asia prior to European expansion in the region, the role of pre-colonial polities in instituting a 'decline' in 'proto-industrialization', and the impact of colonial rule. For an early, but intriguingly scaler intervention into these debates, see Frank Perlin, Unbroken Landscape: Commodity, Category, Sign and Identity: Their Production as Myth and Knowledge from 1500 (Aldershot: Variorum, 1994), 29-87.

${ }^{19}$ On the mutually constitutive world of colonial capital and the bazaar, see also Birla, Stages of Capital; Anand Yang, Bazaar India: Markets, Society, and the Colonial State in Gangetic Bihar (Oxford: Oxford University Press, 1998).

${ }^{20}$ On arbitrage, see Johan Mathew, Margins of the Market: Trafficking and Capitalism Across the Arabian Sea (Berkeley: University of California Press, 2016).
} 
the nineteenth century witnessed the incorporation of European and American merchants and capital into this inter-vernacular world of the bazaar, Indian Ocean merchants finding themselves more deeply imbricated in the institutional landscapes that empire produced. The transactional grammars of the Indian Ocean world began to look more like their European counterparts. It was this process, which we conceive of as a fusion of contractual horizons, that was constitutive of something that we may call 'global capitalism'.

Our usage of the phrase 'global capitalism' is deliberate here. Actors in the Indian Ocean world during the nineteenth century would not have known of a thing called capitalism, and discussed market processes through more specific references to price and to the market for certain goods. Even for historians today, the term seems evasive: at times, it refers to the Industrial Revolution and its attendant social and economic transformations, while at other times it is more deeply rooted in the plantation economies of the Atlantic. ${ }^{21}$ At still other times, it alludes more generally to the circuits and institutions of exchange - of commerce, though of a sort that increasingly became the privilege of a small group of monopolists who used their access to power to extract profits from the rest of the world. ${ }^{22}$ All of these histories were, of course, party to the moment at which Richard Waters wrote out his contracts in Zanzibar. But capitalism was not a pre-packaged set of ideas, institutions, and practices that was exported out from Europe; indeed, our point here is that it was a global co-creation predicated on the processes of translation and commensuration that we highlight here.

Partly because of that, our usage of the category of 'Indian Ocean' here might sometimes feel slippery. Rather than think of the Indian Ocean as a bounded space, we move between multiple scales: we read Richard Waters' transactions on the island of Zanzibar, and scale upwards to see the broader trans-oceanic fabric that these were woven into. The world of the bazaar that Waters conducted his business in included Indians, Arabs, mainland Africans, and islanders from around the region, and echoed into the Bay of Bengal as well. Although we primarily anchor our analysis in the western Indian Ocean, we are less interested in making a claim about the Indian Ocean world as a bounded space than in establishing it as a platform for thinking about the textured contractual processes that constituted a core component of the 'global' in the phenomenon that we call global capitalism.

\section{The Indian Ocean economy in the long nineteenth century}

For decades, the broad consensus among historians was that the vitality of the trading world of Asia was limited to the pre-industrial era, and that by the nineteenth century Asia had become another frontier in the making of a 'global countryside'. ${ }^{23}$ For many Indian Ocean historians, too, the revolutions of the nineteenth century marked the end of the 'old world' of the monsoon trade. ${ }^{24}$ Other scholarship, however, has suggested that, far from being a time of decline, the Indian Ocean's integration into global markets during the nineteenth century largely prompted a period of commercial boom that lasted until sometime in the first half of the twentieth century, ending with either the First World War or the worldwide economic depression of the 1930s. Historians have long established that East Africa experienced a boom in demand for ivory,

\footnotetext{
${ }^{21}$ See, for example, Eric Wolf, Europe and the People Without History (Berkeley: University of California Press, 1984). For a good overview of the literature on slavery and capitalism in the United States, see Scott R. Nelson, 'Who Put Their Capitalism in My Slavery?', Journal of the Civil War Era 5, no. 2 (2015): 289-310.

${ }^{22}$ See also Fernand Braudel, Civilization and Capitalism, 3 vols. (New York: Harper and Row, 1981-84); Immanuel Wallerstein, The Modern World System, 4 vols. (Berkeley: University of California Press, 2011).

${ }^{23}$ Kenneth Pomeranz, The Great Divergence: China, Europe, and the Making of the Modern World Economy (Princeton: Princeton University Press, 2001); Andre Gunder Frank, ReOrient: Global Economy in the Asian Age (Berkeley: University of California Press, 1998).

${ }^{24}$ For a recent articulation of this position, see Prasannan Parthasarathi and Giorgio Riello, 'The Indian Ocean in the Long Eighteenth Century', Eighteenth-Century Studies 48, no. 1 (2014): 12, 14.
} 
plantation products (namely cloves, but also coconuts), and slaves during the nineteenth century, and that this boom set in motion processes of social and political transformation. ${ }^{25}$ The notion of a nineteenth-century boom has recently been extended to other Indian Ocean sectors as well: Arabian dates, Persian Gulf pearls, and Southeast Asian rubber, to name a few - disconnected in time and space, but all part of a broad trend.$^{26}$ Researchers have suggested that this boom period was enormously important to the reconfiguration of economic life in the region, as both producers and consumers reoriented themselves and their activities towards the new horizons. Eschewing a narrative in which Euro-American capital completely subsumed communities and individuals, historians argue that these processes opened up the possibility for new life-worlds and historical trajectories. $^{27}$

Of course, the two positions are hardly exclusive of one another and the tension between subordination and dynamism has proved a productive one. ${ }^{28}$ As a metonym for the range of different financial and organizational practices that animated economic life around the Indian Ocean, the bazaar forms a space from which we might consider the shared boundaries between the local and trans-local trajectories of the Indian Ocean and the changing world of global capitalism. For participants in the maritime bazaar, it might not have been entirely clear that they were undergoing a process of subordination or peripheralization. Instead, they would have likely understood it as a time of massive economic expansion: a moment in which the ivory, cloves, gum copal, dates, hides, and pearls they had been doing business in for centuries made their way to new markets and could command new prices, and in which they could witness the seasonal arrival of ships from England, Germany, France, and the United States alongside the dhows that usually made their way into the harbours. Of course, times were not always so good, and merchants were able to identify and navigate long intervals of commercial downturn and depressed prices as well.

To ride the waves of these nineteenth-century booms and busts, bazaar merchants did what they had done for centuries: adapted and reconfigured their transactional world, incorporating new actors, institutions, and contractual vernaculars. To be clear, we do not envision indigenous forms as persisting unchanged under colonial capitalism. Rather we are interested in how the very logics and tools of cross-cultural trade could be adapted to incorporate not only exchanges with Euro-American capital, but also interactions with the imperial actors and institutions that populated the western Indian Ocean from the mid nineteenth century onwards. We argue that historians have to contend with the local worlds of contracting because it was that vernacular that supplied the language for what the arrival of the 'global' might look like. In the context of the nineteenth-century boom, contracts forged to shape local relationships were gradually adapted to meet the demands of transregional commerce and credit; merchants coming from Europe or the United States had to grapple with, and ultimately adapt themselves to, those very vernaculars. If the bazaar was never local nor static, then the Euro-American networks and institutions that would come to define global capitalism were also being formed in the interface. Such interactions, entanglements, and fusions only become clear, however, if we step into the bazaar itself.

\footnotetext{
${ }^{25}$ Prestholdt, Domesticating the World; Jonathon Glassman, Feasts and Riot: Revelry, Rebellion, and Popular Consciousness on the Swahili Coast, 1856-1888 (Athens, OH: Ohio University Press, 1995); Abdul Sheriff, Slaves, Spices, and Ivory in Zanzibar: Integration of an East African Commercial Empire into the World Economy, 1770-1873 (Athens, OH: James Currey, 1987); Frederick Cooper, Plantation Slavery on the East Coast of Africa (New Haven: Yale University Press, 1977).

${ }^{26}$ Sunil Amrith, Crossing the Bay of Bengal: The Furies of Nature and the Fortunes of Migrants (Cambridge, MA: Harvard University Press, 2013), 101-43; Matthew Hopper, Slaves of One Master: Globalization and Slavery in Arabia in the Age of Empire (New Haven: Yale University Press, 2015), 51-104.

${ }^{27}$ Here, we are borrowing the eloquent phrasing of Tariq Ali, A Local History of Global Capital: Jute and Peasant Life in the Bengal Delta (Princeton: Princeton University Press, 2018), 10. See also Jairus Banaji, Theory as History: Essays on Modes of Production and Exploitation (Leiden: Brill, 2010), 359-60.

${ }^{28}$ Johan Mathew's work goes a long way toward this end, arguing that, rather than outright subordination, the period might be productively thought of as one of 'enframing' - a process by which British officials redrew the boundaries between licit and illicit economic activity in an effort to construct a vision of a self-regulating free market economy. See Matthew, Margins of the Market.
} 


\section{Commerce and contracting in the maritime bazaar}

At the core of the bazaar economy of the Indian Ocean were the bonds of debt and credit - of obligation, more generally - that bound economic actors together, from Basra all the way down to Zanzibar. As the fundamental idiom of economic life, debt (and its counterpart, credit) gave shape to virtually all commercial enterprises in the region, as different actors borrowed capital (in the form of money advances, trading goods, or provisions) from one another and bound themselves, and often their families as well, to deliver a good or perform a service in return. As a durable bond, debt formed the basic building block of a range of different commercial enterprises and 'business firms' around the western Indian Ocean. Through debt and credit, actors around the Indian Ocean forged bonds with one another that helped reduce the costs of determining the price and quantity of goods; in Geertz's words, they transformed 'a diffuse mob into a stable collection of familiar antagonists. ${ }^{29}$ Our understanding of the bazaar as a historical phenomenon allows us to push the boundaries of Geertz's local space; we are interested less in the cultural intimacies that produced familiar antagonists and more with the intersecting contractual vernaculars that allowed for brokerage between cultures. Analysing the material artefacts of the bazaar thus illuminates the processes of translation, conversion, and commensuration that produced the cross-cultural exchanges of that space.

These bonds of debt were most visible on board the dhows that marked the seascapes. In the pearl dive that took place annually around the Persian Gulf in the summer months, divers took a series of loans (a pre-season advance, and two loans in the off-seasons) from their captain (called a nakhoda) to see them through the year; in return, they pledged to dive for that nakhoda and no-one else, effectively binding themselves to the nakhoda's firm. For his part, the nakhoda was bound to a merchant from whom he borrowed the capital; whatever pearls his divers fished that season were to be delivered to the merchant at a discounted rate. A similar system of advances bound mariners to nakhodas of trading dhows in the Persian Gulf and East Africa, the principal difference between trading and pearling being the high uncertainty that characterized profitmaking in the latter (to say nothing of the physical harshness of the activity). ${ }^{30}$

In another mobile labour setting, the caravan trails of East Africa, the bonds of credit and debt were equally pervasive. Aspiring traders could not hope to outfit a caravan into the interior without access to credit from the merchant communities of the coast: it was through these merchants that they accessed the cloth, beads, guns, and other goods necessary to do business in the interior. For their part, coastal merchants made sure to spread their credit among many caravans, lest the volatile politics of the interior disrupt the return of the ivory they invested in. ${ }^{31}$ When it came to particularly successful ivory traders, merchants competed with one another for their clientship. ${ }^{32}$ Others were able to draw on coastal credit through family

\footnotetext{
${ }^{29}$ Geertz, 'Bazaar Economy', 30.

${ }^{30}$ See also 'Notes on the Pearl Fisheries of the Persian Gulf, prepared by Captain E.L. Durand', Administration Report of the Persian Gulf Political Residency and Muscat Political Agency for the Year 1877-78, India Office Records V/23/32, no. 152, British Library, London (hereafter cited as IOR); Peter Lienhardt, Shaikhdoms of Eastern Arabia (Basingstoke: Palgrave, 2001), 114-64; Frauke Heard-Bey, From Trucial States to United Arab Emirates (London: Longman Group, 1996), 208-11. On long-distance trading dhows, see also Yacoub Y. Al-Hijji, Kuwait and the Sea: A Brief Economic and Social History (London: Arabian Publishing, 2010), 42-7, 82-6; Dionysius Agius, Seafaring in the Arabian Gulf and Oman: People of the Dhow (London: Kegal Paul, 2005), 152-4; A. H. J. Prins, Sailing from Lamu: A Study of Maritime Culture in Islamic East Africa (Assem: Van Gorcum, 1965), 213-16; Alan Villiers, 'Some Aspects of the Arab Dhow Trade', Middle East Journal 2, no. 4 (1948): 399-416. The nature of profit-sharing on the pearling and trading dhows, too, was broadly similar. See also Lienhardt, Shaikhdoms of Eastern Arabia, 128.

${ }^{31}$ Glassman, Feasts and Riot, 71-4; Fahad Ahmed Bishara, A Sea of Debt: Law and Economic Life in the Western Indian Ocean, 1780-1950 (Cambridge: Cambridge University Press, 2017), 34-40. These diverse portfolios of investments are evident in Gujarati final accounts included in Consular Court Probate Records housed at the Zanzibar National Archives, Kilimani, Zanzibar, Tanzania (hereafter cited as ZNA). See, for example, HC1/292: 19/1893: Issaji Peerbhoy.

${ }^{32}$ Hamed bin Muhammad Al-Marjebi, Maisha ya Hamed bin Muhammad Al-Marjebi, Yaani Tippu Tip (The life of Hamed bin Muhammad Al-Marjebi, namely Tippu Tip) (Nairobi: East African Literature Bureau, 1974), 29-31.
} 
members who acted as guarantors for them; in return, they accompanied their kinsmen, looked after their goods on the caravan trail, and lent military support to them when the situation called for it. ${ }^{33}$

Similarly, in the plantations of East Africa and South Arabia, ties of debt bound planters to port-based merchants, ensuring the steady movement of produce from farm to market. By mobilizing a variety of different instruments and by sending their agents and employees out to the farm areas to establish and manage accounts with planters, port-based creditors (usually, but not always, Indian merchants) were able to secure a supply of plantation goods for export to markets in South Asia, Europe, and beyond. ${ }^{34}$ In the date farms of southern Iraq, too, merchants from around the Gulf loaned out money to local farmers and landowners in return for supplies of dates that they would then ship by dhow to Indian Ocean markets. ${ }^{35}$ In western India, networks of credit linked cotton farmers and artisans to Bombay mill-owners and wholesale merchants supplying shopkeepers in East Africa and the Gulf. ${ }^{36}$

Though we have discussed all of these sectors separately, they were anything but discrete: all these arenas of economic life blended into one another as capital moved from caravan to plantation and dhow. One can pick any one of these and 'follow the money' into all of the others. Profits made in the ivory trade, for example, were frequently invested in plantations, both on the East African coast and in the date-growing regions of South Arabia. ${ }^{37}$ Gulf merchants who owned date farms in southern Iraq also habitually invested in outfitting pearling dhows, and merchants in both the Gulf and East Africa invariably owned or financed dhows, whose crews would take their produce to markets elsewhere. ${ }^{38}$ In all of these places, merchant loans to rulers and their family members, either in return for the right to farm customs or in the regular course of business, were common; 'the state' was just as bound up in this regional economy of obligation as merchants and planters were. ${ }^{39}$

Although the world of the bazaar was a regional one, the bonds that economic actors forged and the contracts that they drew on to give shape to them were, for the most part, local in their scope. In their most basic form, these contracts looked like promissory notes or IOUs, in which a debtor acknowledged a debt of money and agreed to repay it within a certain amount of time. At the core of each contract was a basic acknowledgement on the part of the borrower; nearly every Arabic contract began with the debtor admitting that obligation. Gujarati instruments increasingly eschewed the more detailed grammars of Indian hundis and mortgages and began instead with a

\footnotetext{
${ }^{33}$ Thomas F. McDow, Buying Time: Debt and Mobility in the Western Indian Ocean (Athens, OH: Ohio University Press, 2018), 117-44

${ }^{34}$ Bishara, Sea of Debt; Hollian Wint, 'Credible Relations: Indian Finance and East African Society in the Indian Ocean, $c$. 1840-1930' (PhD diss. New York University, 2016), 43-117, 183-242; Nancy Um, The Merchant Houses of Mocha: Trade and Architecture in an Indian Ocean Port (Tacoma, WA: University of Washington Press, 2009), 36-47.

${ }^{35}$ See Thabit J. Abdullah, Merchants, Mamluks, and Murder: The Political Economy of Trade in Eighteenth-Century Basra (Albany: SUNY Press, 2001), 88-91; James Onley, 'Transnational Merchants in the Nineteenth-Century Gulf: The Case of the Safar Family', in Transnational Connections and the Arab Gulf, ed. Madawi al-Rasheed (London: Routledge, 2005), 63-71. There is also enough archival material to illustrate this: see the petition from Mohammed Sadiq Safar to the Ottoman Shahbandar of Basra, 15 May 1911, Bushihri Collection, Bahrain (hereafter cited as BC), and the collection of contracts housed in the Al Ibrahim Collection, Kuwait (hereafter cited as AIK).

${ }^{36}$ Wint, 'Credible Relations', 47-69. For an earlier period, see Machado, Ocean of Trade. These multi-scalar credit networks are described in imperial gazetteers and in Gujarati reports. See, for example, Nanji Champsi and Somji Valabhji, Kachchh Desh Sirastra Sangrah: A Digest of Local Customs in the Province of Cutch Relating to Trade and Giras (Bombay: Education Society's Press, 1885).

${ }^{37}$ Bishara, Sea of Debt, 190-216; McDow, Buying Time, 215-59.

${ }^{38}$ On the Gulf, see also Al-Hijji, Kuwait and the Sea, 46-7, 84-6; Hala Fattah, The Politics of Regional Trade in Iraq, Arabia, and the Gulf, 1745-1900 (Albany: SUNY Press, 1997), 76-89; Abdullah, Merchants, Mamluks, and Murder, 67-72. On East Africa, see Prins, Sailing from Lamu, 57, 211-13.

${ }^{39} \mathrm{M}$. Reda Bhacker, Trade and Empire in Muscat and Zanzibar: Roots of British Domination (London: Routledge, 1992), 71-4; Bishara, Sea of Debt, 50-5; McDow, Buying Time, 44-60.
} 
similar third-person acknowledgement. ${ }^{40}$ There were, of course, variations on this, but most signalled the same phenomenon: a recognition on the part of the debtor that he or she 'owed' an amount of money and had agreed to something as part of the obligation - to repay, perform a service, or give up property.

Many (it is impossible to tell how many) were simple IOUs, reflecting no more than what the document itself declared: a one-off loan and a promise to repay. Perhaps just as many, however, constituted a snapshot in time of a much longer relationship, in which the creditor continually re-extended the loan as the debtor serviced it - a relationship in which full repayment signalled the intention to end a relationship, not the regular course of events. We catch glimpses of these durable arrangements in the dissolution, composition, and settlement contracts that Gujarati merchants left behind, many of which refer to the extended periods of vyavhar, a term that denotes the range of transactional domains - financial and social- and long-term temporalities that constituted commercial life in the region. ${ }^{41}$ Ongoing financial relationships, rather than discrete, terminal transactions, defined the temporality of the bazaar.

By drawing parallels between the two sets of materials, we do not mean to suggest that they are indistinguishable. Far from it: these are materials that emerged out of distinct (if historically connected) legal worlds, and that were adapted to the world of Indian Ocean commerce by different sorts of actors. However, the very clear differences between them should not obscure the fact that these materials intersect and overlap with one another in highly generative and productive ways. Thinking about them as populating the same transactional plane thus allows us to read the ways in which they created commensurability, producing the possibilities of brokerage, and of commerce itself.

The intersections between Indian Ocean vernaculars are most evident in the ways that bazaaris translated and converted between different contractual forms. When Gujaratis contracted an obligation through an Arabic deed, they often included a note, usually on the back of the paper, in Gujarati. These notes were rarely direct translations of the Arabic; rather, Gujarati merchants transmuted the arrangement into the social and financial vernacular of the creditor. Sometimes merchants simply translated the debtor's identity into their own understanding of the Indian Ocean social world, describing East African actors as lok (commoner/native) or manumitted slaves as golo (slave). The writers $(k \bar{a} t i b)$ of Arabic deeds performed a similar procedure, creating fictional genealogies for those actors from outside the Arab clan structure. Gujarati notes also included information not included in the original deed, detailing interest rates incorporated into the transaction but elided in the Arabic version. Such notes were transmitted into various account books, which were the sites of multiple conversions and translations, between forms of knowledge and values - calculative and intimate, market prices and negotiated obligations - as well as contractual vernaculars. ${ }^{42} \mathrm{~A}$ merchant's worth could be determined by his final accounts, but the value of his estate depended on his heir's ability to collect on his debts. This was often contingent on the heir's promise to extend future credit or his willingness to renegotiate the accumulated interest noted on the back of Arabic deeds.

\footnotetext{
${ }^{40}$ For East Africa, the contracts housed at the Zanzibar National Archives - specifically, the AM series - provide overwhelming evidence of this. For a searchable database of Arabic materials from the ZNA AM series, see the Ocean of Paper database hosted by the Sultan Qaboos Cultural Center, http://www.indianoceanhistory.org/oceanofpaper/. For materials from Bahrain, see IOR R/15/2/2017 and 2018. Champsi and Valabhji, Kachchh Desh Sirastra Sangrah, details the numerous forms that hundi could take in western India and there are some British references to hundis circulating around the western Indian Ocean (see, for example, IOR L/PJ/6/184: 1467/1887). Yet very few identifiable hundis were registered at the ZNA, though some deeds refer to them (e.g. ZNA AM 8/1: Deed 252 of 1881).

${ }^{41}$ Examples include ZNA AM 2/4: Deed 25 of 1892. Ongoing relations were alternatively referred to as lenden or levādevā (transactions; giving and taking), for example, in AA 12/19: Deed 43 of 1877, and AM 2/1: Deed 70 of 1880.

${ }^{42}$ Wint, 'Credible Relations', 192-7. Johan Mathew makes a similar observation about Arabic account books in Margins of the Market, 155.
} 
Bazaar merchants' ability to translate and convert across financial registers helped to produce (and in turn was facilitated by) the increasing commensurability of Gujarati and Arabic contractual forms. This is most evident in the acknowledgements of debt that were coupled with a pledge of property. The most straightforward form of property pledging was the rahn, in which the debtor temporarily pawned property to his or her creditor until the loan was repaid. Economic actors from around the western Indian Ocean made frequent use of rahns of property most frequently homes and plantations, but also sometimes dhows and other forms of moveable property - as a way of securing access to credit. ${ }^{43}$ Gujarati retailers, both Muslim and Hindu, employed the rahn in coastal East Africa to gain temporary access to enslaved African labour, as well as to secure modest loans to smallholders, wage labourers, neighbours, and family members. ${ }^{44}$ At the same time, they adapted various kinds of pledge contracts (dharanau; ghasgharene) that developed out of western India's dynamic credit market to the needs of East African markets. ${ }^{45}$

Those looking to drum up capital often took to other means of mobilizing their property, too. Sales of property constituted a regular practice around the region, and are as common in the far-flung archive of the bazaar as any other contractual form. Only a portion of these, however, were straightforward sales; many were called khiyār (option) sales, and were either implicitly or explicitly temporary, granting the borrower (or rather, the seller) the option to purchase back the sold property at some agreed-upon moment in the future, or to annul the sale after repaying the loan amount. In some cases, these sales would be coupled with a clause in which the debtorcum-seller agreed to rent back the property in the meantime. ${ }^{46}$ We must thus think of the sales contract as a loan instrument designed to facilitate borrowers' access to capital, and as part of the financial world of the bazaar.

As with other Islamic financial instruments, these pseudo-sales and their conceptual lexicons cut across ethno-religious lines. Gujaratis' familiarity, if not fluency, with the particular grammars of Islamic commercial law resulted from more than the generational accumulation of knowledge; 'conditional transfers' and 'conditional sales' (avadh aghät and avadh vechän), loans in the form of sales that followed similar rules, were common transactions in nineteenth-century western India. ${ }^{47}$ While there is limited evidence of these instruments being employed in other parts of the Indian Ocean, commensurable concepts of property rights, their alienability, and their negotiability structured more broadly Indian Ocean contractual vernaculars.

Through these sorts of instruments, from basic acknowledgements of debt to more complex transactions of property for credit, a wide range of actors were able to enter into the economic arena and participate in the expansive world of the bazaar - merchant-moneylenders and

\footnotetext{
${ }^{43}$ For some illustrative examples, see ZNA AM 3/1: 29-33, 44, 319; ZNA AA 12/19: 591/1876, 131/1877. See also McDow, Buying Time, 13, 59; Machado, Ocean of Trade, 36-8, 64-5; Lienhardt, Shaikhdoms of Eastern Arabia, 158; Nelida Fuccaro, Histories of City and State in the Persian Gulf: Manama Since 1800 (New York: Cambridge University Press, 2009), 100-4; Rahn Deed between Musallam bin Khalil and 'Abdullah bin 'Isa Al-Ibrahim, dated 29 Jumada Al-Thani 1280 (11 December 1863), AIK.

${ }^{44}$ See the analysis of the relationship between Indian credit and enslaved labour in Wint, 'Credible Relations', chap. 2, and the portfolios of Lalji and Meghji Anandji analysed in ibid., chap. 3.

${ }^{45}$ The multiple pledge forms listed in Champsi and Valabhji, Kachchh Desh Sirastra Sangrah, were often simplified into a garene form in East Africa. Examples include ZNA AA 12/19: Deeds 541 of 1876 and 47 of 1877, and AA 12/20: Deeds 659 and 704 of 1885

${ }^{46}$ The ZNA AM series abound with examples of these sorts of sales: see, for example, ZNA AM 2/3, 2/7, 5/1, and 8/2, all available in the Ocean of Paper database. On khiyar sales, see Bishara, Sea of Debt, 90-9; McDow, Buying Time, 13, 59, 262; Elke Stockreiter, Islamic Law, Gender, and Social Change in Post-Abolition Zanzibar (New York: Cambridge University Press, 2015), 218; Elisabeth McMahon, Slavery and Emancipation in Islamic East Africa: From Honor to Respectability (New York: Cambridge University Press, 2013), 102-4. For the Persian Gulf, see also the registered debt contracts in IOR R/15/2/2017 and 2018. For South Arabia, see Linda Boxberger, 'Avoiding Riba: Credit and Custodianship in Nineteenth-Century Hadhramaut', Islamic Law and Society 5, no. 2 (1998): 196-213.

${ }^{47}$ Champsi and Valabhji, Kachchh Desh Sirastra Sangrah, 730-6.
} 
landowners, but also economic actors who are less established in the historiography. Records from coastal Somalia in the 1890s illustrate the frequency with which women engaged in commercial transactions, loaning money to male family members and partners, but also borrowing money and putting up property - real estate, jewellery, livestock, and more - as collateral. ${ }^{48}$ Research from the Zanzibar archipelago, too, demonstrates the preponderance of women in the credit economy, both as lenders (often, but not always, to their male relatives) and as borrowers. ${ }^{49}$ The wives of Gujarati merchants actively mobilized their property in support of their husbands' business endeavours, but they also took to a range of contracts in order to raise credit. ${ }^{50}$

Enslaved Africans, too, entered into the economic arena and displayed a high degree of commercial mobility and autonomy. Although the nineteenth century witnessed a process by which the economic autonomy of the enslaved was increasingly being restricted in a plantation setting (at least in East Africa), this always existed in tension with the opportunities that abounded in the ivory trade and other sectors. ${ }^{51}$ The documentary record illustrates the frequency with which enslaved actors took on loans and entered into contracts to deliver goods - particularly in the East African ivory trade, where opportunities were widespread, but also in the Persian Gulf date and pearl trade. Enslaved and manumitted Africans sometimes acted as creditors, loaning money on a smaller scale to would-be entrepreneurs, generating both profit and reputation in the process. ${ }^{52}$ As the horizons of economic life expanded, then, so too did the range of actors who became interested in entering into the world of commerce, either as prospective entrepreneurs or as moneylenders.

Among the new entrants into the bazaar, those who had access to property had privileged access to credit. And prospective economic actors looked to whatever property they had available in their attempts to leverage access to credit. Inheritance practices in the Islamic world, which tended to fragment estates over the course of generations, often ensured that a broad span of debtors had access to real property or a share in a jointly owned property that they could draw on. ${ }^{53}$ This in part explains the preponderance of women in the credit market: as property owners (often, but not always, through inheritance) they could enter the market as prospective borrowers, but also as lenders. ${ }^{54}$ Similarly, Gujarati widows, who legally had only an inalienable 'lifetime interest' in their husband's property, were some of the most enthusiastic participants in the East African credit economy. ${ }^{55}$ For their part, ex-slaves and other individuals of servile status often pawned huts that they had come to own, either having purchased them outright or having established title to them through other means such as inheritance or cultivation. It was uncommon (though not impossible) to find enslaved or manumitted actors who had access to valuable property. ${ }^{56}$

\footnotetext{
${ }^{48}$ Lidwein Kapteijns and Alessandra Vianello, 'Women's Legal Agency and Property in the Court Records of Late Nineteenth-Century Brava', History in Africa 44 (2017): 133-97.

${ }^{49} \mathrm{McMahon}$, Slavery and Emancipation in East Africa, 147-55; Stockreiter, Islamic Law, Gender, and Social Change, 139-65.

${ }^{50}$ Wint, 'Credible Relations', 204-51.

${ }^{51}$ Jonathon Glassman, 'The Bondsman's New Clothes: The Contradictory Consciousness of Slave Resistance on the Swahili Coast', Journal of African History 32, no. 2 (1991): 277-312.

${ }^{52}$ Thomas McDow, 'Deeds of Freed Slaves: Manumission and Economic and Social Mobility in Pre-Abolition Zanzibar', in Indian Ocean Slavery in the Age of Abolition, ed. Robert Harms, Bernard K. Freamon, and David W. Blight (New Haven: Yale University Press, 2013), 167-75; Bishara, Sea of Debt, 73-8, 142-4; Abdul Sheriff, 'Social Mobility in Indian Ocean Slavery: The Strange Career of Sultan bin Aman', in Indian Ocean Slavery in the Age of Abolition, ed. Harms, Freamon, and Blight, 149-51; McMahon, Slavery and Emancipation in East Africa, 100-5; McDow, Buying Time, 190-214.

${ }^{53}$ On Muslim inheritance practices and estates, see also Timur Kuran, The Long Divergence: How Islamic Law Held Back the Middle East (Princeton: Princeton University Press, 2011), 78-96; Beshara Doumani, Family Life in the Ottoman Mediterranean: A Social History (New York: Cambridge University Press, 2017).

${ }^{54}$ Stockreiter, Islamic Law, Gender, and Social Change, 140-3; Kapteijns and Vianello, 'Women's Legal Agency', 176-88.

${ }^{55}$ Wint, 'Credible Relations', 248-60, 271-86.

${ }^{56}$ McMahon, Slavery and Emancipation in Islamic East Africa, 100-6; McDow, 'Deeds of Freed Slaves', 168-73; Bishara, Sea of Debt, 142-4; Sheriff, 'Social Mobility in Indian Ocean Slavery', 149-54.
} 
The mobilization of property was often more than local in scope: actors invested capital in different sectors, but also in different parts of the Indian Ocean world. Having access to property in multiple locations was particularly useful when commercial booms unfolded in different places at different times. Property in Oman or Basra that might not have been particularly valuable during the East African ivory boom of the early nineteenth century became highly desirable with the surge in the date trade towards the end of the century. Those who had access to property in different locations - whether through family ties, social relations, or other means - were able to parlay resources generated in one boom environment into another, riding the waves that made their way across the Indian Ocean. Other Indian Ocean actors were able to dispose of property across the ocean to gain access to cash, which they would then use to finance political intrigues. ${ }^{57}$ While merchants' use of property across the ocean was not always smooth -and indeed often fuelled court battles that could tie property up for decades - many deeds acknowledged this trans-regional contractual space, noting that the rights and obligations inscribed therein would be upheld 'from country to country' (deshpardesh, which can also be rendered 'at home and abroad'). ${ }^{58}$

Moreover, those who had access to more liquid and mobile forms of capital could respond to the changing vicissitudes of commercial life in the Indian Ocean with remarkable agility. In East Africa and the Persian Gulf, economic actors who owned ships - ocean-going dhows, mediumsized coastal craft, or smaller longboats - regularly pawned these to their creditors when money was tight. ${ }^{59}$ Others drew on other forms of portable wealth - often gold ornaments, but sometimes even farm animals - to access credit when they were unable (or unwilling) to liquidate their real-estate holdings. ${ }^{60}$ And in rare moments of financial urgency, these actors cashed in the most valuable form of wealth that they had: that which they had accumulated in people, whether in the form of indebted mariners or of slaves. ${ }^{61}$

Perhaps the most mobile forms of capital were the deeds themselves. Commercial actors both secured loans by transferring individual deeds and pledged bundles of outstandings (ughräni), illustrating once again the practices of conversion and translation that defined the bazaar. Gujarati composition deeds often incorporated the pledge of specified contractual instruments (called waraqas), while registered Arabic deeds sometimes included notes describing the transfer of paper obligations from one creditor to another. Perhaps more intriguing are the Gujarati deeds mortgaging 'new and old outstandings' owed to debtors in ports around the Indian Ocean. ${ }^{62}$ That merchants felt confident giving and accepting the promise of rights to obligations that were often hundreds of miles apart and even sometimes in very different jurisdictions shows clearly the trans-local and cross-cultural nature of the bazaar.

The transfer of obligations and the movement of rents, credit, and commodities from one corner of this bazaar world to another was in part facilitated by the emergence of a mutually intelligible system of weights and measures, and a shared currency system. Whether one was in Basra, Bahrain, Muscat, Aden, or Zanzibar, the commodities were commensurable to one another. There was the ubiquitous frasila, a unit used to measure cloves, ivory, orchilla weed, and other commodities in East Africa and South Arabia; the chau, a unit used to categorize pearls by weight around the coasts of the Persian Gulf and western India; the mann, a unit for measuring the weight of

\footnotetext{
${ }^{57}$ McDow, Buying Time, 215-59.

${ }^{58}$ Two particularly trans-local examples are ZNA AM 2/4: Deeds 101 of 1891 and 5 of 1892.

${ }^{59}$ See, for example, ZNA AM 9/4: 92, 118, 164, 382; AM 8/2: Deed 2 of 1893; IOR R/15/2/2018: 26.

${ }^{60}$ ZNA AM 3/1: 381, 528, 575, 576; AM 8/1: Deed 251 of 1881; AM 9/4: 376; Rashid Karmali vs Sherbanoo (1908) 1 Zanzibar Law Reports (hereafter cited as ZLR) 254.

${ }^{61}$ ZNA AM 1/3: 13, 47, 344, 424, 534.

${ }^{62}$ ZNA AM 2/3: Deeds 1103 of 1886 and 1521 of 1887. David Rudner notes that Chettiar financial instruments circulated as commodities, even as they symbolized and constituted different local obligations, though he understands these as distinct 'spheres of exchange'. See David Rudner, 'Banker's Trust and the Culture of Banking Among the Nattukottai Chettiars of Colonial South India', Modern Asian Studies 23, no. 3 (1989): 417-58.
} 
dates, barley, flour, and other staples; the güniya, an Arabic term used to refer to gunny sacks of various commodities; and a host of other units for different goods around the region. Although there was a fair amount of inconsistency in what these measures signified - one port's frasila was not the same as another's - the record makes it clear that regional merchants were able to convert between these with facility, producing a form of transregional commensurability. ${ }^{63}$ And circulating around the coasts were a handful of different currencies - principally Indian rupees and Maria Theresa dollars (alternatively referred to as qurush, riyals, or $r \bar{a} l$ ) - that virtually everyone did business in and converted between. ${ }^{64}$

And yet, for all of the exchanges of goods and promises, few of these things had a set value. Deeds attesting to the commodities that people transacted in and the property that they exchanged to access credit often suggested a link between an item transacted and the consideration given, but virtually all commentators on this world, from Basra to Zanzibar, have pointed out that the amount stated on the form was hardly ever accurate - that merchants in this world engaged in a variety of contractual ruses and sleights of hand in order to conceal the nature of their transactions. Attempts, too, at finding a formula for determining the relationship between a loan and the value of property put up as collateral are invariably frustrated by the wild inconsistencies that the deeds reflect in the valuation of property.

Rather than take these as straightforward ruses, we might interpret them as highlighting just how situational and dramatic notions of value could be. ${ }^{65}$ When an entrepreneur took on an advance of goods and money and repaid with commodities like ivory or cloves, there was no sense that there was a market value that aggressively intervened in the enumeration of credits and debts between the parties, but rather a subtle process of negotiation that factored in past, present, and future. The value of a property put up as collateral reflected less its market value (though that might have intervened at some stage of the negotiations) than it did the often asymmetrical relationship between the creditor and debtor; so too for the price of credit - the rate of interest. The social relations of debt and credit worked to minimize uncertainty when it came to doing business around the Indian Ocean world, reducing the costs of determining the price and quality of goods. Such commercial intimacies, however, were neither culturally determined nor static; a well-played negotiation over the exchange of capital and goods may solidify a future relationship, while a poor performance in the past could increase the cost of future transactions. Thus, while value was situated and negotiated within the social world of the bazaar, relationships between creditors and debtors were simultaneously reconstituted and transformed through the 'tournaments of value' at different regional interfaces. ${ }^{66}$ What mattered, then, was less the market price than the bazaar price - a value that emerged out of the relationship between the parties and the process of negotiation itself.

Even as merchants, moneylenders, and other economic actors mobilized property, money, and contracts to form very local relationships, then, they always looked elsewhere - to other partners, other sectors, other forms of capital, and other corners of the Indian Ocean - to find the resources they needed to stay afloat. The investment frontiers of big merchants and petty traders alike were wide, and were constantly moving. Through the multitude of transactions, big and small, in which

\footnotetext{
${ }^{63}$ See Fahad Ahmad Bishara, 'Paper Routes: Inscribing Islamic Law Across the Nineteenth-Century Western Indian Ocean', Law and History Review 32, no. 4 (2014): 814-17; Heard-Bey, From Trucial States, 189; Robert Carter, Sea of Pearls: Seven Thousand Years of the Industry that Shaped the Gulf (London: Arabian Publishing, 2012), 242-57; Al-Hijji, Kuwait and the Sea, 56-9; Saif Al-Shamlan, Tārīkh Al-Ghawș 'alā Al-Lu'lu' fì Al-Kuwayt wal-Khalīj Al-'Arabī, vol. 2 (Kuwait: Dhāt as-Salāsil Press, 1975), 291-304.

${ }^{64}$ For discussions of changing currency markets in the western Indian Ocean, see Mathew, Margins of the Market, 113-42; Charles Schaefer, 'Selling at a Wash: Competition and the Indian Merchant Community in Aden Crown Colony', Comparative Studies in South Asia, Africa, and the Middle East 19, no. 2 (1999): 16-23.

${ }^{65} \mathrm{On}$ the drama of asymmetrical exchanges, see Guyer, Marginal Gains, 40.

${ }^{66}$ Arjun Appadurai, 'Introduction: Commodities and the Politics of Value', in The Social Life of Things: Commodities in Cultural Perspective, ed. Arjun Appadurai (New York: Cambridge University Press, 1986), 3-63.
} 
they engaged, they forged a regional property market. And although not everyone enjoyed the same mobility, nor the same opportunities to invest abroad - most bazaar transactions were, after all, very local - the broader contours of the regional market for property would have been known to all and experienced, at least second- or third-hand, by many.

\section{Law in the bazaar}

But what of the work of drawing up a legal framework for this changing economic world? As a historical phenomenon, cross-cultural trade was deeply embedded in contractual forms and legal practices in which economic actors engaged to bridge between different spheres of exchange. Recent work has highlighted how different legal actors all played a role in shaping the workings of law in the Indian Ocean marketplace: Muslim jurists and judges (qadis), as well as less prominent legal actors such as scribes (kätibs) ${ }^{67}$ Gujarati merchants often did the work of translating socio-financial vernaculars themselves, though larger firms likely retained the services of professional clerks (mehtā; gumāshtā) and less-established (and less-literate) traders seem to have relied on the skills and reputation of elite merchants. Economics and legal actors together therefore shaped the contractual world of the maritime bazaar, enabling the forms of translation and brokerage that animated trade across continents.

But regional juridical actors were only part of the story: the record makes it overwhelmingly clear that Indian Ocean actors did not shy away from turning to other legal institutions to manage their local and regional transactions; law formed a critical component of the world of commerce. The world of the bazaar was not one of seamless connection: however attractive 'trust' might be as a framework for understanding trade outside the Euro-Atlantic world, it is not usefully pitted against law; the two can work together to coordinate action or can work towards very different aims within the same commercial relationship. ${ }^{68}$ And, as many now recognize, for every successful transaction - for every moment for which merchants smoothed out matters of translations and commensurability through their contracts - there was one that generated confusion, mistranslation, or conflict, and bazaar merchants drew on a variety of legal resources in working these matters out. At different junctures throughout the nineteenth and twentieth centuries, and for a range of different reasons, creditors and debtors from Basra to Zanzibar sought to involve European (principally British, but also German and French) courts in the contractual disputes they found themselves embroiled in. As they did with the Portuguese courts in Mozambique during the late eighteenth and early nineteenth centuries, Indian merchants in particular took to European courts with enthusiasm. ${ }^{69}$ Around the Indian Ocean, economic actors of all backgrounds sued their business partners over allegations of financial mismanagement, litigated for access to family-held property, and regularly lodged claims against their debtors. At the same time, actors from the region began to routinely register their contracts at European consulates, hoping to establish an evidentiary baseline for future litigation. ${ }^{70}$

\footnotetext{
${ }^{67}$ Bishara, Sea of Debt, 58-106; Brinkley Messick, The Calligraphic State: Textual Domination and History in a Muslim Society (Berkeley: University of California Press, 1993), 226-41.

${ }^{68}$ The literature on trust in economic history is enormous, and has highlighted a number of different configurations between 'trust' and 'law' in regulating commercial affairs. On trust and trade in Indian Ocean trade specifically, see also Trivellato, Familiarity of Strangers, 153-93; Aslanian, From the Indian Ocean, 166-201; Markovits, Global World of Indian Merchants, 260-5.

${ }^{69}$ Machado, Ocean of Trade, 48-57; Aslanian, From the Indian Ocean, 198-9; Gagan Sood, India and the Islamic Heartlands: An Eighteenth-Century World of Circulation and Exchange (Cambridge: Cambridge University Press, 2016), 164-86.

${ }^{70}$ Scott Reese, Imperial Muslims: Islam, Community, and Authority in the Indian Ocean, 1839-1937 (Edinburgh: Edinburgh University Press, 2017), 79-108; Bishara, Sea of Debt, 125-49; McMahon, Slavery and Emancipation, 100-1; Stockreiter, Islamic Law, Gender, and Social Change, 139-66. The majority of the extant deeds from the Persian Gulf and East Africa have survived in archived consular court registers.
} 
The legal landscape of the bazaar, then, often included elements of what historians might consider to be colonial institutions - a phenomenon that even the most expansive interpretation of the bazaar does not account for. Moreover, the record makes it clear that, unlike colonial officials, judges and lawyers were less interested in imposing a property rights regime onto the bazaar world of contracting than they were in making sense of the competing rights and obligations that ran through it. Court cases and published law reports from East Africa and the Persian Gulf all reflect a tendency to accommodate, make sense of, and regulate bazaar contracts rather than do away with them altogether. ${ }^{71}$ This was decidedly not the case in South Asia, though, where colonial courts took a heavier hand in regulating transactions in property and money from the mid nineteenth century onwards. ${ }^{72}$ Nevertheless, even colonial courts often shied away from intervening in cases that extended beyond the formal boundaries of the British empire. ${ }^{73}$

Perhaps unsurprisingly, the regularity with which Indian Ocean merchants took to European courts around the Indian Ocean left its imprint on the contracts in which they engaged. As merchants drew the lexical system of Anglo-Indian law into their transactions with one another, they too became entangled in its registers and began to resemble their reflections in the mirror of the law. Perhaps most striking are the Gujarati contracts that refer to the mortgage - written as märgijj, the transliterated English word - of property in East Africa and western India. Commercial actors mortgaging property in the colonial city of Bombay registered English deeds in Zanzibar that translated Gujarati social spaces and obligations into Anglo-Indian legal lexicons and forms. And Gujarati deeds increasingly included references to consular registers and court cases as additional layers of regulation. ${ }^{74}$ Others ostensibly appeared stable in that they retained their original names, but through iterative legal contests had become substantively redefined so as to better fit with English nominate contracts. The khiyār sale, which was widely employed in South Arabia and East Africa, was gradually redefined as a 'mortgage by conditional sale' as merchants in East Africa drew on a growing body of Indian and English lawyers to litigate their commercial disputes in court. ${ }^{75}$ Similar processes gradually redefined the obligations between Gujarati principals and their agents so as to more closely fall in line with Indian legal practice; one wonders whether other contracts in other Indian Ocean contexts might have undergone similar transformations as they made their way through British courts and into the imperial legal scaffolding that law reports slowly erected. ${ }^{76}$ The record thus suggests that these contracts were not at all static, but were always approaching other contractual lexicons in a process that resembled a form of legal isomorphism.

The institutional landscape of bazaar commerce, too, began to fill the mould into which British judges had cast them: in East Africa, Indian merchant councils like mahājans and panchäyats became the indigenous tribunals that British and other European courts imagined them to be, while in the Persian Gulf the ahl al-sālifah informal body of arbiters in disputes of maritime custom became formalized as the 'salifah court'. One might as easily think of how these processes

\footnotetext{
${ }^{71}$ See generally, Law Reports Containing Cases Determined by the High Court for Zanzibar and on Appeal Therefrom by the Court of Appeal for Eastern Africa and by the Privy Council, 3 vols. (Zanzibar Government Printers, 1919-61). See also the records from the Political Agent's Court, Bahrain, IOR R/15/3 series.

${ }^{72}$ See Birla, Stages of Capital; Julia Stephens, Governing Islam: Law, Empire, and Secularism in South Asia (New York: Cambridge University Press, 2018); Gregory Kozlowski, Muslim Endowments and Society in British India (New York: Cambridge University Press, 1995); Rachel Sturman, The Government of Social Life in Colonial India: Liberalism, Religious Law, and Women's Rights (New York: Cambridge University Press, 2012).

${ }^{73}$ See, for example, Kessowji Damodar Jairam v. Khimji Jairam (1888) 12 Indian Law Reports 507.

${ }^{74}$ For an example of a margij deed that mortgages various waraqa and a havalo (transfer deed), see ZNA AA 12/20: Deed 715 of 1885. See also ZNA AM 2/4: Deeds 65 and 75 of 1891 and AM 2/3: Deed 1103 of 1886.

${ }^{75}$ See Said bin Awad vs Mahfuz bin Ahmed (1906), 1 ZLR 189; The British Resident vs Hafiz bin Mohammed Al-Busa'idi (1916) 1 ZLR 526; Mohammed bin Mahfuth, by his Attorney Omar bin Abdullah vs Abdullah bin Salim (1930) 2 ZLR 9.

${ }^{76}$ See Prebji Khimji vs Tyebji Mamoonji (1878) 1 ZLR 7. The shah-gumastha system that Claude Markovits discusses in his work would be a prime example, as Markovits himself draws at least some of his insights from court records and registered contracts. Markovits, Global World of Indian Merchants, 156-84.
} 
took shape in the bazaar's past, too, as Armenian merchants, Indian merchants, and other groups fused their tribunals to the institutional horizons of other empires. ${ }^{77}$ All of this is to say nothing, of course, of the broader juridical transformations wrought under British colonialism, including the creation of altogether new legal forums for 'native' litigants and mixed-status conflicts. ${ }^{78}$

The contractual world of the bazaar was thus neither local nor static. The transactions that actors entered into were deeply entangled in the changing economic and political landscape, and actively adapted themselves to the new commercial and institutional horizons that life in the Indian Ocean presented. Over the course of the nineteenth and early twentieth centuries, the boundaries between the contractual world of the bazaar and the consular court became more porous; the grammars that had distinguished one from the other became increasingly fused to one another, much like the forms of the bazaar themselves had become entangled in one another earlier on. It is virtually impossible, then, to imagine a world of bazaar contracting as a totally indigenous money market, and less still as one that evolved independently of Western financial institutions. The bazaar of contracts was one that was always in flux, adapting to the new legal and commercial frontiers that lay before it - sometimes successfully, and other times in ways that generated tension and conflict, necessitating legal contests. Looking outwards from the bazaar, then, the coming of Euro-American and colonial capital has to be understood as layering another dimension onto a world that was already in motion, rather than reconfiguring it altogether.

\section{Entangled vernaculars}

We are now well equipped to return to and make sense of the stack of contracts left behind by Richard Waters from his time as American consul in Zanzibar, in which English-language contracts sat alongside (and sometimes were embedded within) their Gujarati and Arabic counterparts. What is immediately striking about these papers are the breaches in the contractual fabric that allow the historian to peer into the world of the bazaar that Waters did business in: a world of changing forms of brokerage and attempts at translation across commercial systems. At times, these involved exactly the same sorts of contracts we have explored above: one deed in Waters' papers involves an acknowledgement by a Zanzibar merchant, Mohammed bin 'Abdulqadir, that he was to deliver 600 kurjas of Lamu and Brava hides to Waters within a year. The document looks virtually identical to the sorts of contracts we have laid out here, and Waters' 'translation' is not an attempt at translating at all, but rather a brief summary of its contents with an explanation of how many of the hides had been delivered to date, and at what prices. ${ }^{79}$ It, and others like it, illustrate how Waters' business affairs were imbricated in the documentary world of the bazaar, and highlight the degree to which he relied on its vernaculars - particularly when it came to regional commodities like hides.

Other bazaar ephemera made their way into the collection as well: it includes a number of receipts from different merchants for money they received from Waters as payment for goods. ${ }^{80}$ Gujarati notes at the end of the English contracts resemble those written on the back of waraqas and indicate that these transactions were also being translated into various kinds of vernacular

\footnotetext{
${ }^{77}$ Markovits, Global World of Indian Merchants, 256-7; Fuccaro, Histories of City and State in the Persian Gulf, 161-3; Heard-Bey, From Trucial States, 111, 209-10; Machado, Ocean of Trade, 52-7; Aslanian, From the Indian Ocean, 166-201; 'Correspondence regarding the Diving Court', IOR R/15/2/1902.

${ }^{78}$ On the creation of a 'dual jurisdiction' in Zanzibar, see Stockreiter, Islamic Law, Gender, and Social Change, 27-45. For similar processes in Bahrain, see Hussain Al-Baharnah, British Extra-Territorial Jurisdiction in the Gulf 1913-1971: An Analysis of the System of British Courts in the Territories of the British Protected States of the Gulf During the Pre-Independence Era (Slough: Archive Editions, 1998); James Onley, The Arabian Frontier of the British Raj: Merchants, Rulers, and the British in the Nineteenth-Century Gulf (Oxford: Oxford University Press, 2007): 119-27; Stephens, Governing Islam, 40-56.

${ }^{79}$ Richard P. Waters Papers, MH14 Box 2, Folder 6, PEM.

${ }^{80}$ Richard P. Waters Papers, MH14 Box 3, Folders 5-7, PEM.
} 
ledgers. Even their marking of the fulfilment of the contract was the same: much as Arabic and Gujarati deeds in the bazaar would often be destroyed upon fulfilment, the ones that made their way into Waters' papers were crossed out or cut out when the parties were satisfied that they had been fulfilled; his agreement with Mohammed bin 'Abdulqadir was crossed out in pen, the word 'Satisfied' scrawled over the text of the agreement. ${ }^{81}$ In many cases, only the English versions remain wholly intact. ${ }^{82}$

More revealing, however, are the differences between the English contracts on the one hand and the Arabic and Gujarati contracts on the other - the disconnects and slippages, particularly in the amount of detail they offer. On the whole, the English versions of the contracts give more detail: they relate the very specific quantities and qualities of goods being transacted in, the details of the delivery, and, more tellingly, the amount paid for them. The Arabic and Gujarati versions of the contracts, and the bazaar world of contracts they reflect more generally, are often vague when it comes to one or more of these features: though they frequently identify quantities of goods exchanged, they only sometimes discuss delivery details or the quality of the goods expected, and almost never mention prices. In one striking example from the Waters collection, an English contract with three Gujarati trading partners exchanging kegs of gunpowder for ivory and copal details not only the rated pricing and delivery details but also the exact quality demanded (for the ivory, above a certain weight and 'free from splits and cracks'; for the copal, 'cleaned and sifted as usual' and conforming to an existing sample), and even where the product was to be prepared. ${ }^{83}$ The Gujarati version was much shorter, including the rates and delivery dates, but omitting all other details. The contract followed the standard Indian Ocean vernacular form and it is likely that these details were either already assumed (indeed, the language of Waters' contract hints at this also) or negotiated at a later date.

This last point is important. As we suggested earlier, notions of value in the world of the bazaar were situational and dramatic; property, commodities, and even the price of credit itself (measured as interest) reflected the going market rate, but were tempered by the specific context of the relationship between the contracting parties. When the value of an object transacted was quantified, there was often an enormous amount of variation in that value, which could hardly stand in for market price. One might therefore read Waters' own English version of the contracts as an attempt to translate this world into a contractual idiom that was more legible (and sensible and reliable) to him, adding in the necessary detail that was left unsaid, or firming up the values that were usually more malleable and negotiated in a bazaar contract - in other words, to make the Indian Ocean world of the bazaar commensurable with his own. Read this way, his contracts reflect an attempt by Waters to adjust to the world of the bazaar, but on his own contractual terms - much as Indian Ocean merchants would do in British courts several decades later.

And yet the process was not unidirectional. The parts of the Arabic and Gujarati contracts that make them seem unfamiliar - their willingness to take the bazaar vernacular and rearrange it to read more like an English contract, and, more importantly, to supply details up front on weights, measures, and sometimes even value, when they would not have otherwise - all suggest that Waters' business associates were also willing to adjust their contracts and expectations, at least on paper. And in making Indian Ocean vernaculars more commensurable with EuroAmerican ones, they drew on a long history of translation and conversion. In the Waters papers, then, we see what we might think of as an early example of legal fusion - a moment in which brokers from different spheres of exchange worked to stretch their own vocabularies and formulas to meet those of their exchange partners. The contracts stop short of the wholesale bleeding together of legal forms and epistemologies that would characterize the late nineteenth and early

\footnotetext{
${ }^{81}$ Richard P. Waters Papers, MH14 Box 2, Folder 6, PEM.

${ }^{82}$ On deeds and their destruction, see Bishara, Sea of Debt, 246.

${ }^{83}$ Contract dated 20 April 1842, Richard P. Waters Papers, MH14 Box 2, Folder 6, PEM.
} 
twentieth centuries, but are nonetheless illuminative in the breaches in the fabric they present to us: a textured view of global capital from the bazaar, supplied by those who brokered across its seams.

\section{Reflection}

Reading Richard Waters' contracts, the historian is immediately tempted to see them as simply attempts by Waters to render the world of the bazaar equivalent to his own commercial and legal lexicon. In doing so, we situate these as worlds that are somehow sealed off from one another, mediated by brokers who reached over from one system into another. It is an image that accords well with prevailing understandings of cross-cultural trade in world history. But, instead of thinking of the two through the prism of unidirectional translation, we might read them as reflecting the entanglements and fusions between the local, regional, and global commercial and legal forms that had characterized bazaar life in the western Indian Ocean during the nineteenth and early twentieth centuries. It is certainly true that Euro-American capital always had to adapt to the local vernaculars of the bazaar economy, but those local vernaculars were themselves in a state of change, as bazaar merchants and juridical actors stretched them to meet the opportunities and challenges of a shifting economic and legal world. Cross-cultural trade, then, necessitated a regular practice of legal and commercial translation and conversion, allowing the forms of brokerage and entanglement that would produce global capitalism as a historical phenomenon.

Thinking of the documentary worlds of the bazaar and of Euro-American capitalism (and of their mutual forms) alongside and entangled in one another is not to suggest that they were seamless; far from it. Just as local and regional bazaar transactions sometimes sat uneasily with one another, so too did the bazaari and the Euro-American. Evidence abounds of legal disputes between members of European firms and their Indian Ocean partners, ranging from small case files tucked away in small archives around the region to larger disputes that made their way into published law reports and before the Privy Council. The stacks of copied contracts that were filed away in Richard Waters' papers ought not to be taken, then, as evidence of a frictionless and frustration-free process. Quite the opposite: his keenness on keeping copies of contracts in duplicate might be an indication of his readiness to litigate when he needed to.

Nor should any of this suggest that Euro-American capitalism arrived in an Indian Ocean bazaar world that had been static; we cannot posit a vernacular world that somehow remained unchanged until the arrival of American and European merchants. Instead, we have to situate the arrival of European and American merchants in the context of a world that was already in flux, one in which the contractual lexicon of the local formed the grammars of the transregional - and, through its interfaces with European and American contracts, ultimately the global too. The Indian Ocean was thus not simply a place that felt the impact of global forces; it was an arena in which regional commercial dynamics laid the groundwork for those very global forces, and in which the global nested itself within a transactional world that emerged out of regional and local concerns. ${ }^{84}$

Still, despite the entanglements that characterized this world from the top to the bottom, these contracts present us with an opportunity to think about the big narratives of world economic history from a vantage point other than the European perspectives that have dominated world and global history thus far. What we are treated to here is a view of the global looking outwards from the bazaar - a view of large-scale processes grounded in a different vernacular, and marked by different temporalities. This was not a world that was ever closed off from the global, but it was one in which the principal concerns and attachments were local and regional, and in which global

\footnotetext{
${ }^{84}$ Here we are drawing on the astute remarks of David A. Bell in the forum 'Discussion: The Futures of Global History', Journal of Global History 13, no. 1 (2018): 17-18.
} 
commerce was just one of many horizons - a broad and capacious bazaar, but one that 'drags us back necessarily to a deep, local history'. ${ }^{85}$

Fahad Ahmad Bishara is Associate Professor of History and Rouhollah Ramazani Professor of Arabian Peninsula and Gulf Studies at the University of Virginia. He writes on the history of law and capitalism in the Indian Ocean world, and is currently working on a history of the Indian Ocean dhow trade.

Hollian Wint is Assistant Professor of History at the University of California, Los Angeles. She is currently working on a book that explores financial and familial networks in the Indian Ocean (with specific reference to East Africa) in the nineteenth and twentieth centuries.

\footnotetext{
${ }^{85}$ John-Paul Ghobrial, 'The Secret Life of Elias of Babylon and the Uses of Global Microhistory', Past \& Present 222, no. 1 (2013): 59 .
}

Cite this article: Bishara F. and Wint H. 2021. Into the bazaar: Indian Ocean vernaculars in the age of global capitalism. Journal of Global History 16: 44-64, doi:10.1017/S174002282000011X 